
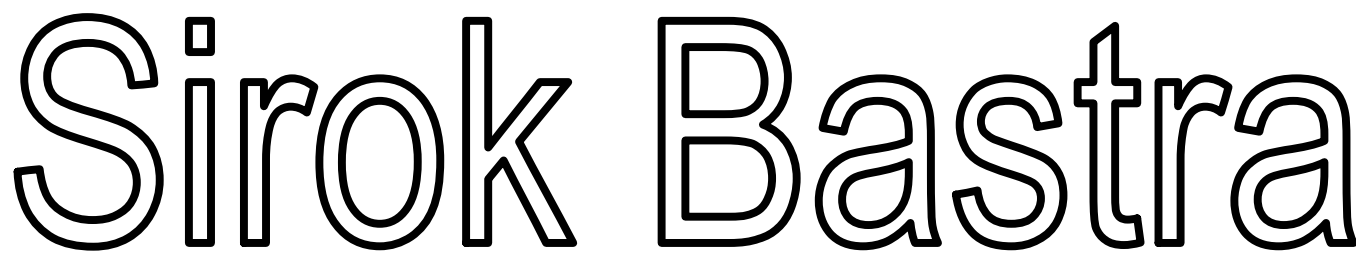

J URNAL ILMIAH KEBAHASAAN DAN KESASTRAAN

\begin{tabular}{|c|c|c|c|c|c|}
\hline $\begin{array}{c}\text { Sirok Bastra } \\
\text { Jurnal Kebahasaan dan } \\
\text { Kesastraan }\end{array}$ & Volume 5 & Nomor 2 & $\begin{array}{c}\text { Hlm. } \\
101-196\end{array}$ & $\begin{array}{c}\text { Pangkalpinang, } \\
\text { Desember } \\
2017\end{array}$ & $\begin{array}{c}\text { ISSN } \\
2354-7200\end{array}$ \\
\hline
\end{tabular}

KANTOR BAHASA KEPULAUAN BANGKA BELITUNG 


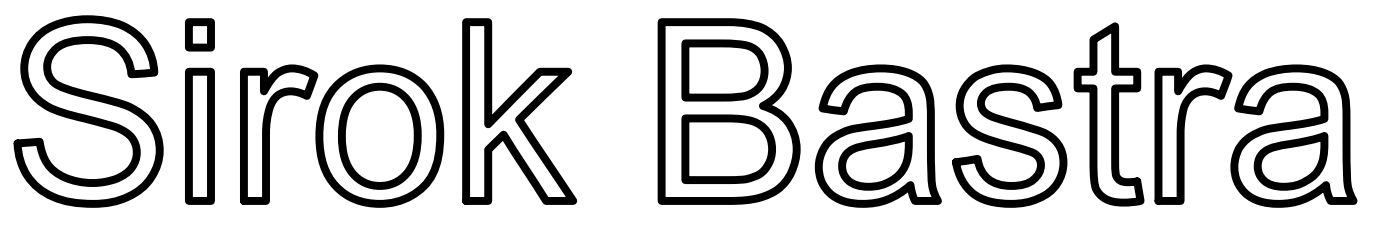

\section{J URNAL ILMIAH KEBAHASAAN DAN KESASTRAAN}

Jurnal ini merupakan wadah informasi kebahasan, kesastraan, dan pengajarannya yang memuat hasil penelitian, studi kepustakaan, dan tulisan ilmiah bidang kebahasan dan kesastraan serta pengajarannya. Sirok Bastra terbit dua kali setahun, yakni Juni dan Desember, serta terbit sejak Juni 2013.

\section{Penanggung Jawab}

Kepala Kantor Bahasa Kepulauan Bangka Belitung

Drs. Hidayatul Astar, M.Hum.

\section{Mitra Bestari}

Prof. Dr. Agus Nuryatin, M.Hum. (Bidang Sastra dan Pengajarannya)

Prof. Amrin Saragih, Ph.D., M.A. (Bidang Bahasa dan Pengajarannya)

Dr. Felicia Nuradi Utorodewo, M.Hum. (Bidang Bahasa dan Pengajarannya)

Dr. Pujiharto, M.Hum. (Bidang Sastra dan Pengajarannya)

\section{Pemimpin Redaksi}

Rahmat Muhidin, S.S.

\section{Penyunting}

Dr. Asyraf Suryadin, M.Pd.

Prima Hariyanto, S.Hum.

Sarman, S.Pd.

\section{Perancang Sampul}

Feri Pristiawan, S.S.

\section{Pengatak}

Dewi Septi Kurniawati, S.Kom.

\section{Kesekretariatan \\ Ria Anggraini, S.E. Juliati, S.E.}

\section{Alamat Redaksi dan Penerbit}

Kantor Bahasa Kepulauan Bangka Belitung

Jalan Letkol Saleh Ode No. 412, Kota Pangkalpinang, Prov. Kepulauan Bangka Belitung Telepon (0717) 438455, Faksimile(0717)9103317, Pos-el: sirokbastra@gmail.com, sirokbastra@kemdikbud.go.id

Pemuatan suatu tulisan dalam jurnal ini tidak berarti redaksi menyetujui isi tulisan tersebut. Isi tulisan menjadi tanggung jawab penulis. Tulisan telah ditinjau dan diulas oleh mitra bestari. Setiap karangan dalam jurnal ini dapat diperbanyak setelah mendapat izin tertulis dari penulis, redaksi, dan penerbit. 


\section{PENGANTAR}

Puji syukur ke hadirat Pemilik dan Pencipta semesta ini yang memiliki kuasa atas diri-Nya sendiri. Dialah Tuhan Yang Maha Esa yang telah memberikan rahmat dan hidayah-Nya sehingga Volume 5 Nomor 2 Jurnal Sirok Bastra Tahun 2017 dapat terbit tepat pada waktunya.

Pada edisi ini dimuat sepuluh tulisan, yakni lima tulisan kebahasaan, empat tulisan kesastraan, dan satu tulisan pengajaran sastra.

Dalam penelitiannya, Hotnida Novita Sary menganalisis iklan komersial Meikarta yang telah membuat perusahaan tersebut berhasil mencatatkan penjualan yang fantastis. Penelitian yang dilakukannya menggunakan pisau bedah analisis wacana kritis Fairclough (1989). Iklan Meikarta membandingkan kesuperioritasan mereka dibandingkan kota metropolitan lain, seperti Jakarta. Meikarta juga menanamkan ideologi bagi masyarakat kota besar bahwa kota metropolitan saat ini sudah tidak aman, kotor, dan macet.

Dalam makalahnya, Hidayatul Astar mengkaji realisasi konsep bahasa Indonesia ke dalam bahasa Rejang. Menurutnya, masyarakat Rejang tidak memiliki konsep (kata atau istilah) yang cukup untuk mewakili pikiran dan perasaan tertentu ketika berkomunikasi, terutama yang terkait dengan konsep kehidupan modern atau yang sesuai dengan perkembangan zaman. Karena itu, bahasa Rejang perlu memungut atau mengambil dari bahasa lain, khususnya dari bahasa Indonesia. Realisasi bentuk konsep yang ditemukan adalah realisasi tanpa perubahan dan realisasi dengan perubahan. Berdasarkan data, realisasi perubahan dalam sebuah konsep dapat satu kali atau lebih. Realisasi perubahan itu berupa penghilangan, penggantian, dan penambahan bunyi vokal atau konsonan tertentu pada posisi tertentu. Terjadinya perubahan realisasi bunyi bahasa Indonsia ke dalam bahasa Rejang disebabkan oleh keinginan penutur bahasa Rejang dan adaptasi terhadap bunyi yang sudah ada.

Dalam kajiannya, Mardi Nugroho membahas pembentukan kata dalam bahasa Talondo di Sulawesi Barat. Hasil analisis data menunjukkan bahwa ada tiga macam cara pembentukan kata dalam bahasa Talondo, yaitu afiksasi, reduplikasi, dan pemajemukan. Pembentukan kata dengan afiksasi terdiri atas pembentukan kata dengan prefiksasi, konfiksasi, infiksasi, dan sufiksasi. Pembentukan kata dengan reduplikasi terdiri atas reduplikasi murni, reduplikasi sebagian, dan reduplikasi yang berkombinasi dengan afiksasi.

Dalam kajiannya, Muhammad Fadely membahas makna dan bentuk pemakaian eufemisme dan disfemisme dalam feature karya Ruslan Ismail Mage yang bermanfaat bagi pengajaran bahasa Indonesia dan pengembangan bahasa di media massa cetak. Hasil analisis menunjukkan bahwa pemakaian eufemisme lebih banyak daripada pemakaian disfemisme. Berdasarkan simpulan tersebut, peneliti menyarankan bahwa dalam menyampaikan suatu informasi kepada khalayak umum hindari tulisan-tulisan yang dapat mengaburkan dan tidak terus terang demi maksud-maksud tertentu.

Dalam kajiannya, Asri Soraya Afsari membahas karakteristik bahasa yang digunakan dalam iklan komersial ponsel yang berada di Kota Bandung. Hasil penelitian menunjukkan bahwa bentuk dan fungsi bahasa yang digunakan dalam iklan ponsel di Kota Bandung berupa penulisan huruf kapital secara keseluruhan dan penulisan huruf kapital pada awal kata. Bahasa iklan ponsel memiliki fungsi informatif dan konatif (persuatif).

Dalam tulisannya, Erwin Wibowo mendeskripsikan makna semiotik budaya Lampung yang ada di dalam antologi Kitab Cerpen Perempuan di Rumah Panggung. Hasil penelitian mengungkapkan ikon, indeks, dan simbol budaya Lampung melalui pendekatan semiotik yang dipakai dalam Kitab Cerpen Perempuan di Rumah Panggung karya Isbedy Stiawan ZS dan memberi deskripsi tentang ikon, indeks, dan simbol tesebut.

Dalam penelitiannya, Prima Hariyanto membahas penokohan dalam Kitab Omong Kosong yang mengambil cerita epos Ramayana. Dalam novel ini, pengarang mengubah pola cerita. Tokoh sentral dalam cerita ini bukan lagi Rama dan Sinta, tetapi Maneka dan Satya. Ceritanya bukan lagi kisah cinta Rama dan Sinta, tetapi kisah perjalanan Maneka dan Satya dalam mencari Kitab Omong Kosong ciptaan Hanoman. Tokoh Rama tidak lagi diceritakan sebagai kesatria yang baik, tetapi sebagai raja yang membawa bencana bagi rakyat di muka bumi.

Dalam kajiannya, Dian Anggraini mengkaji intertekstual lima puisi Indonesia yang berisi tentang sosok wanita yang disebut ibu, yaitu "Ibu Dehulu" (Amir Hamzah), "Ibu” (Chairil Anwar), "Sajak Ibu” (Wiji Thukul), 
"Bunda Air Mata" (Emha Ainun Najib"), dan "Ibu” (K.H. Mustofa Bisri). Hasil telaah itu membuktikan bahwa kelima puisi tersebut merupakan mosaik, kutipan-kutipan, penyerapan, dan perspektif yang beragam terhadap sosok ibu. Setiap penyair mengungkapkan sisi ibu dari pandangan yang berbeda.

Dalam kajiannya, Yuliadi M.R. membahas makna ground dalam cerpen "Uak dan Burung Gagak" dengan pendekatan objektif melalui teori semiotik Pierce. Berdasarkan kajian, terungkap bahwa makna ground dalam cerpen Uak dan Burung Gagak, yaitu ground qualisign berupa warna hitam, sinsign berupa suara koakkoak, dan legisign berupa perilaku mengitari rumah.

Dalam tulisannya, Abdul Azis dan Hajrah membahas dongeng sebagai bahan pembelajaran di sekolah dasar. Data penelitian ini adalah dongeng Cerita Si Jingkiriq, I Kukang, Nenek Pakande, La Dana dan Kerbaunya, dan Puang Tedong. Hasil analisis data dan temuan menunjukkan bahwa rata-rata penilaian responden untuk dongeng sebesar 3,75 (kategori layak dijadikan bahan ajar). Bahan ajar yang dapat digunakan untuk tingkat SD adalah dongeng yang isinya sesuai dengan karakteristik, pengalaman, dan kebutuhan siswa.

Kami mengucapkan terima kasih kepada para penulis yang telah bersedia menerbitkan karya mereka pada edisi ini. Para penulis merupakan peneliti, pakar, dosen, dan mahasiswa dari berbagai perguruan tinggi dan instansi. Terima kasih juga kami sampaikan kepada para mitra bestari kami yang telah memberi ulasan terhadap tulisan-tulisan yang masuk ke redaksi.

Demi memenuhi keberagaman isi dan penulis, Sirok Bastra membuka kesempatan bagi para peneliti dan penulis menyampaikan hasil penelitian dan pemikiran mutakhir dalam bidang kebahasaan, kesastraan, dan pengajarannya. 


\section{UCAPAN TERIMA KASIH UNTUK MITRA BESTARI}

Redaksi Sirok Bastra mengucapkan terima kasih kepada para mitra bestari yang telah meninjau, menimbang, dan mengulas makalah-makalah yang diterbitkan dalam Sirok Bastra Volume 5 Nomor 2, edisi Desember 2017, yakni

Prof. Dr. Agus Nuryatin, M.Hum.

Bidang Sastra dan Pengajarannya

Universitas Negeri Semarang

Semarang, Jawa Tengah

Prof. Amrin Saragih, Ph.D., M.A.

Bidang Bahasa dan Pengajarannya

Universitas Negeri Medan

Medan, Sumatra Utara

Dr. Felicia Nuradi Utorodewo, M.Hum.

Bidang Bahasa dan Pengajarannya

Universitas Indonesia

Depok, Jawa Barat

\section{Dr. Pujiharto, M.Hum.}

Bidang Sastra dan Pengajarannya

Universitas Gadjah Mada

Yogyakarta, Daerah Istimewa Yogyakarta 


\section{DAFTAR ISI}

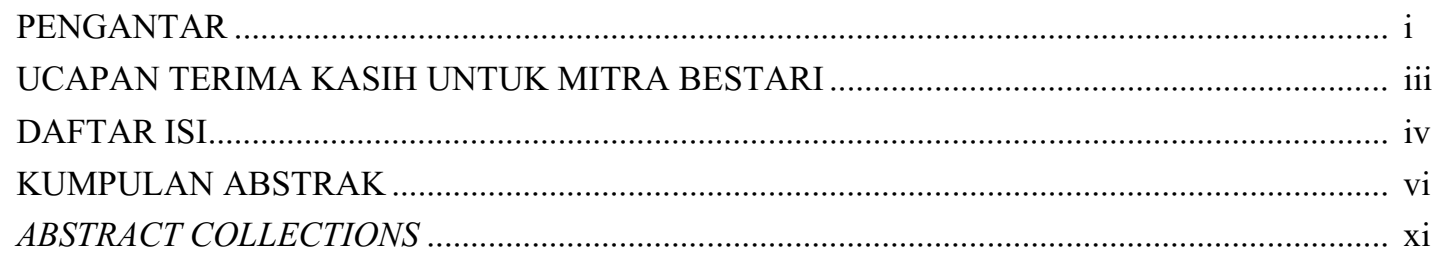

ANALISIS WACANA KRITIS IKLAN KOMERSIAL MEIKARTA

(Critical Discourse Analysis of Meikarta Commercial Advertising)

Hotnida Novita Sary $101-111$

REALISASI KONSEP BAHASA INDONESIA DALAM BAHASA REJANG

(Realization of Indonesian Concept Into Rejang Language)

Hidayatul Astar. $113-121$

PEMBENTUKAN KATA DALAM BAHASA TALONDO

(The Word Formation in Talondo Language)

Mardi Nugroho $123-129$

EUFEMISME DAN DISFEMISME PADA FEATURE-FEATURE KARYA RUSLAN ISMAIL MAGE

(Euphemism and Disphemism in The Features by Ruslan Ismail Mage)

Muhammad Fadely $131-139$

KARAKTERISTIK PENGGUNAAN BAHASA DALAM IKLAN PONSEL DI KOTA BANDUNG

(The Characteristic of Language Usage on Mobile Phone Advertisement in Bandung) Asri Soraya Afsari $141-151$

SIMBOL BUDAYA LAMPUNG DALAM KITAB CERPEN PEREMPUAN DI RUMAH PANGGUNG KARYA ISBEDY STIAWAN Z.S.: KAJIAN SEMIOTIKA

(Lampung Cultural Symbols in Kitab Cerpen Perempuan di Rumah Panggung by Isbedy Stiawan Z.S.: a Semiotic Analysis)

Erwin Wibowo $153-161$

PENOKOHAN DALAM KITAB OMONG KOSONG KARYA SENO GUMIRA AJIDARMA (Characterization in Kitab Omong Kosong by Seno Gumira Ajidarma)

Prima Hariyanto $163-169$

WANITA ISTIMEWA: KAJIAN INTERTEKSTUAL TERHADAP PUISI-PUISI TENTANG IBU

(Special Woman: Intertextual Study of Poems About Mother) 
BURUNG GAGAK SEBUAH TANDA: MAKNA GROUND DALAM CERPEN UAK DAN BURUNG GAGAK

(Brids Crow A Sign: Ground Meaning in Uak and Burung Gagak Short Story)

Yuliadi M.R.

DONGENG SEBAGAI BAHAN PEMBELAJARAN BAHASA INDONESIA DI SEKOLAH

DASAR

(Folktale as Indonesian Language Learning Material in Elementary School)

Abdul Azis dan Hajrah

$191-196$ 
Abdul Azis dan Hajrah: Dongeng sebagai Bahan Pembelajaran Bahasa Indonesia di Sekolah Dasar

\title{
DONGENG SEBAGAI BAHAN PEMBELAJARAN BAHASA INDONESIA DI SEKOLAH DASAR
}

\section{Folktale as Indonesian Language Learning Material in Elementary School}

\author{
Abdul Azis dan Hajrah \\ Fakultas Bahasa dan Sastra UNM Makassar \\ Jalan Dg. Tata Raya, Parangtambung, Makassar \\ Po-el: azissa17@yahoo.co.id
}

(diterima 16 Juli 2017, disetujui 19 Oktober 2017, revisi terakhir 17 Desember 2017)

\begin{abstract}
Abstrak
Pembelajaran sastra di sekolah selalu disorot para pengamat dan peminat sastra. Hal tersebut harus diminimalkan. Pembelajaran harus mampu menciptakan materi yang menarik dan suasana yang kondusif. Metode penelitian ini adalah metode deskriptif analitik. Data penelitian ini adalah dongeng Cerita Si Jingkiriq, I Kukang, Nenek Pakande, La Dana dan Kerbaunya, dan Puang Tedong. Pengumpulan data dilakukan dengan teknik dokumentasi dari guru SD Kabupaten Maros. Teknik analisis meliputi proses pengorganisasian dan pengurutan data tentang dongeng dan pemilihan bahan ajar ke dalam pola kategori dan satuan uraian. Hasil analisis data dan temuan menunjukkan bahwa rata-rata penilaian responden untuk dongeng sebesar 3,75 (kategori layak dijadikan bahan ajar). Bahan ajar yang dapat digunakan untuk tingkat SD adalah dongeng yang isinya sesuai dengan karakteristik, pengalaman, dan kebutuhan siswa.
\end{abstract}

Kata kunci: dongeng, layak, bahan ajar

\begin{abstract}
Literary learning in schools is being center of attention by observers, and literary enthusiasts. It should be minimized and be able to create interesting material and a conducive atmosphere. The method used in this research is an analytic descriptive method. The data in this study are Cerita Si Jingkiriq, I Kukang, Nenek Pakande, La Dana dan Kerbaunya, dan Puang Tedong. All of the data collected by documentation technique from elementary school teacher of Maros Regency. Analytical techniques including the process of organizing and sorting data about the tale and selection of teaching materials into the categories and units of description. The results showed that the average assessment of respondents for the tale is 3.75 (category worthy of being used as teaching materials). Teaching materials that can be used for elementary level is a fairy tale that suits with the characteristics, experiences, and needs of students.
\end{abstract}

Keywords: fairy tale, worthy, teaching materials

\section{PENDAHULUAN}

\subsection{Latar Belakang}

Dalam Kurikulum Tingkat Satuan Pendidikan (KTSP), pembelajaran cerita rakyat termasuk dalam standar kompetensi yang harus diajarkan oleh guru dalam materi pembelajaran sastra. Hal ini menunjukkan bahwa materi dongeng merupakan materi yang dapat menunjang tujuan pembelajaran sastra di sekolah.

Tujuan pembelajaran sastra pada tiap-tiap dan tingkatan sekolah pada dasarnya sama, hanya saja ada perbedaan tekanan sehubungan dengan jenis dan tingkatan sekolah, yaitu menumbuhkan keterampilan berbahasa. Rahmanto (2013:16) mengatakan bahwa pengajaran sastra dapat membantu pendidikan secara utuh apabila cakupannya meliputi empat manfaat, yaitu membantu keterampilan berbahasa, meningkatkan pengetahuan budaya, mengembangkan cipta dan rasa, dan menunjang pembentukan watak. Membahas perihal pengajaran sastra di sekolah, tujuan yang harus dicapai adalah siswa mampu menikmati, menghayati, memamahi, dan memanfaatkan karya sastra; untuk mengembangkan 
kepribadian, memperluas wawasan kehidupan, serta meningkatkan pengetahuan dan kemampuan berbahasa. Hal itu merupakan salah satu problem dalam pengajaran sastra di sekolah. Seharusnya, guru mengajak siswa keluar, ke alam terbuka dan membantu mereka dalam proses penciptaan karya sastra.

\subsection{Masalah}

Masalah penting yang sering dihadapi guru dalam kegiatan pembelajaran adalah memilih atau menentukan materi pembelajaran atau bahan ajar yang tepat dalam rangka membantu siswa mencapai kompetensi. Hal ini disebabkan oleh kenyataan bahwa dalam kurikulum atau silabus, materi bahan ajar hanya ditulis secara garis besar dalam materi pokok. Tugas guru di lapangan (sekolah) untuk menjabarkan materi pokok tersebut sehingga menjadi bahan ajar yang lengkap.

Ada beberapa hal yang melatari terpinggirkannya pengajaran sastra. Pertama, persentase pengajaran sastra pada kurikulum kita kecil sekali dibandingkan mata pelajaran lain. Pengajaran sastra di SD boleh dikatakan hanya sebagai pelengkap. Kedua, kebanyakan pengajar hanya mengajarkan sastra sebatas teori dan hafalan, tidak menekankan pada apresiasi. Ketiga, kurangnya bahan bacaan sastra. Bagi sekolah yang memiliki perpustakaan memadai, ketersediaan buku bacaan sangat mencukupi sehingga siswa dapat membaca beragam buku sastra. Namun, sebagian besar sekolah belum memiliki perpustakaan yang baik. Itu diperparah dengan rendahnya minat baca. Keempat, penghargaan terhadap karya sastra merupakan pengakuan bahwa sastra setara dengan ilmu lain. Di negara maju, penghargaan terhadap karya sastra dan sastrawan jauh lebih baik.

\subsection{Tujuan}

Penelitian ini bertujuan untuk kepentingan alternatif bahan ajar dan hasil pembelajaran bahasa Indonesia di SD. Selanjutnya, tujuan penelitian adalah untuk mengetahui dan menemukan tingkat kelayakan dongeng guna dijadikan alternatif bahan pembelajaran bahasa dan sastra Indonesia di SD.

\subsection{Metode}

Metode yang digunakan dalam penelitian ini adalah metode deskriptif analitik. Metode analisis kualititif sesuai dengan hakikatnya adalah data yang telah terkumpul diseleksi, dikelompokkan, dilakukan pengkajian, interpretasi, dan disimpulkan. Selanjutnya, hasil simpulan dideskripsikan.

Data dalam penelitian ini berupa dongeng dalam masyarakat. Pengambilan data dari dongeng yang telah dipublikasikan ini didasarkan pertimbangan bahwa masalah yang muncul pada terbitan masyarakat tersebut lebih bervariasi. Pengambilan data ini juga disesuaikan dengan kemampuan tenaga, waktu, dan biaya yang ada. Partisipan merupakan guru yang mengajar Bahasa Indonesia di kelas kelas V dan VI Sekolah Dasar di Kabupaten Maros, Provinsi Sulawesi Selatan. Sumber data data dalam penelitian ini ditentukan dengan purposive sampling yang merupakan cara pengambilan data berdasarkan karakteristik tertentu yang dimiliki sumber data sesuai dengan tujuan penelitian.

Pengumpulan data dilakukan dengan teknik dokumentasi dan observasi dengan menelusuri dongeng yang telah dipublikasi lembaga resmi pemerintahan provinsi; memilih dan menentukan teks yang memenuhi persyaratan untuk diteliti; menganalisis dongeng dari aspek isi untuk mengungkapkan karakteristik yang mendukung dongeng sebagai alternatif bahan ajar; mendeskripsikan data yang telah ditabulasikan; dan membuat laporan penelitian.

Setelah dianalisis, data dongeng dideskripsikan. Data yang dideskripsikan adalah aspek penyusunan pemilihan bahan ajar dari dongeng yang telah dipublikasi lembaga resmi pemerintahan daerah/provinsi. Berdasarkan langkah tersebut, semua data hasil pemilihan dongeng dikelompokkan berdasarkan aspek pemilihan dongeng sebagai bahan ajar kemudian ditabulasikan. Pedoman analisis digunakan untuk mendeskripsikan pemilihan dongeng menjadi bahan ajar yaitu untuk mengetahui aspek tingkat kelayakan dongeng sebagai bahan ajar. 


\section{KERANGKA TEORI}

Pemilihan bahan ajar sastra meliputi identifikasi terhadap bacaan dongeng dan penemuan bahan bacaan tambahan serta alternatif yang akan digunakan di sekolah dan tingkat kemampuan pemahaman siswa atau kemampuan siswa menguasai bahan ajar. Tingkat kemampuan siswa menguasai bahan ajar suatu dongeng merupakan hal penting yang harus dipertimbangkan dalam pemilihan bacaan sebagai bahan ajar.

Penulis berharap penelitian ini dapat menemukan bahan ajar dongeng dan meningkatkan hasil pembelajaran sastra di SD. Masalah penting yang sering dihadapi guru dalam kegiatan pembelajaran adalah memilih atau menentukan materi pembelajaran atau bahan ajar yang tepat dalam rangka membantu siswa mencapai kompetensi.

Ada beberapa prinsip yang perlu diperhatikan dalam penyusunan bahan ajar dongeng atau bahan ajar. Prinsip-prinsip dalam pemilihan bahan ajar meliputi prinsip relevansi, konsistensi, dan kecukupan.

Prinsip relevansi artinya keterkaitan. Bahan ajar hendaknya relevan dengan pencapaian standar kompetensi dan kompetensi dasar. Sebagai contoh, jika kompetensi yang diharapkan dikuasai siswa berupa menghapal fakta, bahan ajar yang diajarkan harus berupa fakta atau bahan hapalan.

Prinsip konsistensi artinya keajegan. Jika kompetensi dasar yang harus dikuasai siswa empat macam, bahan ajar dongeng yang harus diajarkan juga harus meliputi empat macam. Sebagai contoh, kompetensi dasar yang harus dikuasai siswa adalah pementasan karya sastra yang meliputi alur, perwatakan, tema, dan amanat; materi yang diajarkan juga harus meliputi jenis keempatempatnya.

Prinsip kecukupan artinya materi yang diajarkan hendaknya cukup memadai dalam membantu siswa menguasai kompetensi dasar yang diajarkan. Materi tidak boleh terlalu sedikit, dan tidak boleh terlalu banyak. Jika terlalu sedikit akan kurang membantu mencapai standar kompetensi dan kompetensi dasar. Sebaliknya, jika terlalu banyak akan membuang- buang waktu dan tenaga yang tidak perlu untuk mempelajarinya.

Urutan penyajian (sequencing) bahan ajar dongeng sangat penting untuk menentukan urutan mempelajari atau mengajarkannya. Tanpa urutan yang tepat, jika di antara beberapa bahan ajar mempunyai hubungan yang bersifat prasyarat (prerequisite), hal tersebut akan menyulitkan siswa dalam mempelajarinya. Sebagai contoh, materi unsur intrinsik dan ektrinsik dongeng. Siswa akan mengalami kesulitan mempelajari unsur intrinsik dan ektrinsik dongeng jika materi apresiasi dongeng belum dipelajari. Siswa akan mengalami kesulitan dalam mempelajari apresiasi dongeng jika materi pengertian dongeng belum dipelajari.

Bahan ajar yang sudah ditentukan ruang lingkup serta kedalamannya dapat diurutkan melalui dua pendekatan pokok, yaitu pendekatan prosedural dan hierarkis. Urutan bahan ajar secara prosedural menggambarkan langkah-langkah secara urut sesuai dengan langkah-langkah melaksanakan suatu tugas, misalnya langkah-langkah menganalisis dongeng.

Urutan bahan ajar secara hierarkis menggambarkan urutan yang bersifat berjenjang dari bawah ke atas atau dari atas ke bawah. Materi sebelumnya harus dipelajari dahulu sebagai prasyarat untuk mempelajari materi berikutnya.

\section{HASIL DAN PEMBAHASAN}

\subsection{Deskripsi Data Penelitian}

Temuan dan analisis pemilihan dongeng menjadi bahan ajar dibagi menjadi sepuluh bagian. Semua dongeng yang diteliti dan dianalisis kesesuaian isinya dengan bahan ajar berjumlah lima dongeng, yakni Cerita Si Jingkiriq, I Kukang, Nenek Pakande, La Dana dan Kerbaunya, dan Puang Tedong.

Secara umum, rata-rata penilaian responden yang berkaitan pemilihan dongeng sebagai bahan ajar pembelajaran Bahasa Indonesia di SD adalah 3,75 atau pada kategori layak dijadikan bahan ajar.

\subsection{Pembahasan Hasil Penelitian}

Temuan dan analisis yang berkaitan dengan aspek pemilihan dongeng sebagai bahan ajar pembelajaran Bahasa Indonesia di SD dibagi menjadi sepuluh 
bagian. Pertama, aspek berkaitan dengan bahasa dongeng sesuai tingkat kemampuan berbahasa siswa, hasilnya adalah 3,5 atau pada kategori layak dijadikan bahan ajar.

Kedua, aspek situasi dongeng sesuai tingkat kemampuan berbahasa siswa, hasilnya adalah 3,8 atau pada kategori layak dijadikan bahan ajar. Ketiga, aspek berkaitan dengan isi dongeng sesuai tingkat kemampuan berbahasa sisswa, hasilnya adalah 4,075 atau pada kategori layak dijadikan bahan ajar. Keempat, aspek ungkapan/referensi dongeng sesuai tingkat kemampuan berbahasa siswa, hasilnya adalah 3,45 atau pada kategori layak dijadikan bahan ajar. Kelima, aspek berkaitan dengan isi dongeng sesuai tingkat perkembangan kematangan psikologis siswa, hasilnya adalah 3,875 atau pada kategori layak dijadikan bahan ajar.

Keenam, aspek latar belakang budaya dongeng sesuai kondisi lingkungan belajar siswa, hasilnya adalah 3,875 atau pada kategori layak dijadikan bahan ajar. Ketujuh, aspek dongeng membantu keterampilan berbahasa siswa, hasilnya adalah 4,075 atau pada kategori layak dijadikan bahan ajar. Kedelapan, aspek dongeng meningkatkan pengetahuan budaya siswa, hasilnya adalah 3,875 atau pada kategori layak dijadikan bahan ajar. Kesembilan, aspek dongeng mengembangkan cipta dan rasa siswa, hasilnya adalah 3,7 atau pada kategori layak dijadikan bahan ajar. Kesepuluh, aspek dongeng menunjang pembentukan watak siswa, hasilnya adalah 3,525 atau pada kategori layak dijadikan bahan ajar.

Secara umum, rata-rata penilaian responden kesesuaian aspek isi dongeng dengan bahan ajar pembelajaran Bahasa Indonesia di SD adalah 3,775 atau pada kategori layak dijadikan bahan ajar.

\subsection{Kriteria Bahan Ajar Dongeng yang Baik}

Sebelum melaksanakan pemilihan bahan ajar dongeng, perlu diketahui kriteria pemilihan bahan ajar dongeng. Kriteria pokok pemilihan bahan ajar dongeng adalah standar kompetensi dan kompetensi dasar. Hal ini berarti bahwa bahan ajar dongeng yang dipilih untuk diajarkan oleh guru di satu pihak dan harus dipelajari siswa di lain pihak hendaknya berisi materi atau bahan ajar dongeng yang benar- benar menunjang tercapainya standar kompetensi dan kompetensi dasar. Dengan kata lain, pemilihan bahan ajar dongeng harus mengacu atau merujuk pada standar kompetensi.

Setelah diketahui kriteria pemilihan bahan ajar dongeng, dilanjutkan pada langkah-langkah pemilihan bahan ajar dongeng. Secara garis besar langkah-langkah pemilihan bahan ajar dongeng meliputi hal-hal berikut.

a. Mengidentifikasi aspek yang terdapat dalam standar kompetensi dan kompetensi dasar yang menjadi acuan pemilihan bahan ajar dongeng.

b. Mengidentifikasi jenis-jenis materi bahan ajar dongeng.

c. Memilih bahan ajar dongeng yang sesuai atau relevan dengan standar kompetensi dan kompetensi dasar yang telah teridentifikasi.

d. Memilih sumber bahan ajar dongeng.

\section{PANUTUP}

\subsection{Simpulan}

Berdasarkan analisis data, pembahasan hasil penelitian, dan temuan yang telah diuraikan sebelumnya, dapat disimpulkan bahwa aspek pemilihan dongeng yang diteliti berjudul Cerita $\mathrm{Si}$ Jingkiriq, I Kukang, Nenek Pakande, La Dana dan Kerbaunya, dan Puang Tedong. Sebagai bahan ajar, aspek dongeng dibagi menjadi sepuluh subaspek, yaitu subaspek berkaitan dengan bahasa dongeng sesuai tingkat kemampuan berbahasa siswa, situasi dongeng sesuai tingkat kemampuan berbahasa siswa, berkaitan dengan isi dongeng sesuai tingkat kemampuan berbahasa siswa, ungkapan/referensi dongeng sesuai tingkat kemampuan berbahasa siswa, berkaitan dengan isi dongeng sesuai tingkat perkembangan kematangan psikologis siswa, latar belakang budaya dongeng sesuai kondisi lingkungan belajar siswa, dongeng membantu membantu keterampilan berbahasa siswa, dongeng meningkatkan pengetahuan budaya siswa, dongeng mengembangkan cipta dan rasa siswa, dan dongeng menunjang pembentukan watak siswa. Rata-rata penilaian responden kesesuaian aspek pemilihan 
dongeng dengan bahan ajar adalah 3,75 (layak dijadikan bahan ajar).

\subsection{Saran}

Bahan ajar dongeng yang dapat digunakan dalam pembelajaran pada dasarnya adalah jenis dongeng apa saja. Namun, sebaiknya untuk tingkat SD, bahan ajar dongeng yang digunakan adalah dongeng yang isinya sesuai dengan karakteristik, pengalaman, dan kebutuhan siswa. Tujuannya untuk menemukan masalah yang mungkin terdapat dalam bahan ajar dan solusinya agar bahan ajar tersebut benar-benar layak digunakan dalam pembelajaran.

Bacaan yang baik untuk siswa adalah bacaan yang tingkat keterbacaanya tidak terlalu sukar dan tidak juga terlalu mudah. Oleh sebab itu, untuk pembelajaran, sebaiknya menggunakan bahan ajar dongeng yang memiliki tingkat keterbacaan yang tergolong sedang. Idealnya, bahan ajar dongeng yang baik adalah bahan ajar dongeng yang mudah dipahami oleh siswa. Oleh sebab itu, tingkat keterbacaan dongeng untuk bahan pelajaran perlu dipertimbangkan.

Dalam pembelajaran dongeng, siswa juga dikondisikan dalam suasana pembelajaran yang menyenangkan. Siswa bebas menggunakan materi belajar yang dimiliki, khususnya untuk mendalami pemahaman terhadap isi bacaan (dongeng). Dalam hal ini, siswa dapat memahami secara total maknamakna atau hal-hal terpenting yang tersebar dalam bahan ajar dongeng.

Melalui dongeng ini, guru pun lebih semangat memberikan materi pembelajaran dongeng kepada siswa. Dalam hal ini, guru tidak perlu lagi mendominasi pembelajaran, tetapi dengan menggunakan dongeng ini guru semakin aktif untuk memotivasi siswa agar berpikir lebih kritis dan bersikap aktif.

Berdasarkan hal di atas, agar proses pembelajaran sama-sama menyenangkan bagi siswa dan guru, sebaiknya dalam pembelajaran dongeng guru menggunakan dongeng yang ada di lingkungan siswa.

\subsection{Ucapan Terima Kasih}

Dengan selesai dan dimuatnya artikel hasil penelitian ini, penulis menyampaikan rasa hormat yang setinggi-tingginya dan terima kasih yang tiada terkira kepada Dr. Kisman Salija, M.Pd., selaku Dekan Fakultas Bahasa dan Sastra Universitas Negeri Makassar dan Prof. Dr. H. Jufri, M.Pd., Ketua Lembaga Penelitian Universitas Negeri Makassar atas izin keluasan yang diberikan kepada penulis untuk melakukan penelitian. Bupati Kabupaten Maros, Ir. H.M. Hatta Rahman, M.M.; Asisten I Sekretariat Kabupaten Maros Maros, Drs. Muhammad Alwi, M.Si., dan Kepala Badan Kesatuan Bangsa dan Politik Kabupaten Maros atas fasilitas dan bantuan yang diberikan selama penelitian. Muhammad Yunus, S.Pd., M.Pd. (Kepala SDN 3 Maros), Abdul Kadir Salamang, S.Pd. (Kepala SDN 210 Inpres Bontokamase), Hj. Sueba, S.Pd. (Kepala SDN 110 Inpres Galaggara), Kisman, S.Pd. (Kepala SDN 133 Inpres Talawe), Mukhtar, S.Pd. (Kepala SDN 62 Palisi), Abdul Azis, S.Pd., M.Pd. (Kepala SDN 189 Inpres Cambajawa), Bakhtiar, S.Pd. (Kepala SDN 185 Inpres Salomatti), dan Hj. Sendang, S.Pd.I. (Kepala SDN 165 Inpres Abbekae) yang berkenan memberikan izin untuk mengadakan penelitian di sekolahnya masing-masing. Penghargaan yang sepantasnya juga penulis sampaikan kepada Nurhaedah, S.Pd. (Guru Kelas VI SDN 3 Maros), Hasri (Guru Kelas VI SDN 210 Inpres Bontokamase), Nurliah, S.Pd. (Guru Kelas VI SDN 110 Inpres Galaggara), Radiah, S.Pd. (Guru Kelas VI SDN No. 133 Inpres Talawe), Masnah, S.Pd. (Guru Kelas VI SDN 62 Palisi), Satriani, S.Pd. (Guru Kelas VI SDN 189 Inpres Cambajawa), Hermansyah, S.Pd. (Guru Kelas VI SDN 185 Inpres Salomatti), dan Halim, S.Pd. (Guru Kelas VI SDN 210 Inpres Abbekae) atas kesediaanya bermitra dan menjadi teman peneliti selama pengumpulan data penelitian. 
Abdul Azis dan Hajrah: Dongeng sebagai Bahan Pembelajaran Bahasa Indonesia di Sekolah Dasar

\section{DAFTAR PUSTAKA}

Azis, Abdul. 2010. Cerita Pendek pada Surat Kabar sebagai Bahan Ajar: Laporan Hasil Penelitian. Bandung: LPM UPI.

. 2011. "Pemilihan Cerita Pendek dalam Surat Kabar sebagai Bahan Ajar dan Hasil Pembelajaran Bahasa dan Sastra Indonesiadi Sekolah Menengah Atas" dalam Jurnal Metasastra. Bandung: Balai Bahasa Bandung.

2012. Cerita Pendek: Sebagai Bahan Ajar. Bandung: STKIP Siliwangi.

Azis, Abdul, Hajrah. 2015. Pemilihan Cerita Rakyat sebagai Bahan Ajar Pembelajaran Bahasa dan Sastra Indonesia di Sekolah Dasar: Laporan Hasil Penelitian Hibah Bersaing 2015. Makassar: Lemlit UNM Makassar.

Depdiknas. 2006. Kurikulum 2006 Standar Kompetensi Pelajaran Bahasa Indonesia SD dan MI. Jakarta: Departemen Pendidikan Nasional.

Elmubarok, Zain. 2013. Membumikan Pendidikan Nilai, Mengumpulkan yang Tersesak, Menyambung yang Terputus dan Menyatukan yang Tercerai. Bandung: Alfabeta.

Haryati, Mimin. 2007. Model dan Teknik Penilaian pada Tingkat Satuan Pendidikan. Jakarta: Gaung Persada Press.

Mustakim, Muh. Nur. 2012. Peranan Cerita dalam Pembentukan Perkembangan Anak TK. Jakarta: Depdiknas.

Musfiroh, Tadkiratum. 2012. Bercerita untuk Anak Usia Dini, Panduan Bagi Guru Taman Kanak-Kanak. Jakarta: Depdiknas.

Nur Helina, Andi. 2012. Nilai Edukatif Dongeng Tolaki. Kendari: Kantor Bahasa Sulawesi Tenggara: Depdiknas.

Nurgiyantoro, Burhan. 2012. Sastra Anak: Pengantar Pemahaman Dunia Anak. Yogyakarta: Gadjah Mada University Press.

Rahmanto, B. 2013. Metode Pengajaran Sastra. Yogyakarta: Kanisius.

Sidu, La Ode. 2015. "Nilai-Nilai Pendidikan dalam Cerita Rakyat Sulawesi Tenggara," dalam Jurnal Humanika No. 15, Vol. 3, Desember 2015.

Sugiaraga, Made, dkk. 2011. Sastra Lisan Tentu Belu: Analisis Struktur dan Nilai Budaya. Jakarta: Pusat Pembinaan dan Pengembangan Bahasa.

Tillman. 2009. Pembelajaran Pendidikan pada Anak. Jakarta: Depdiknas

Uniawati, dkk. 2009. Materi Dongeng pada Pelajaran Bahasa Indonesia di SD 1 Sonai, Unaaha. Kendari: Kantor Bahasa Provinsi Sulawesi Tenggara.

Wahyuddin, Wisrawati. 2016. "Kemampuan Menentukan Isi Cerita Rakyat Siswa Kelas X SMA Negeri Raha," dalam Jurnal Bastra Vol. 1, No. 1, Maret 2016. 